\title{
HETEROGENEITY OF THINKING: CASE OF RELIGION
}

\author{
Alisa Rekunova \\ Tallinn University/Institute of Natural Sciences and Health (Estonia)
}

\begin{abstract}
According to Lev Vygotsky's cultural-historical theory, thinking goes through four stages: syncretic concepts, everyday concepts, pseudoconcepts, and true (structural-systemic, by Aaro Toomela) concepts. Toomela suggested, that religious beliefs tend to form on the stage of everyday concepts. The first step of the work was to distinguish different stages of concepts in the human mind by examining the words the person uses during an interview. The second step was to examine whether there any contradictions between religious and scientific concepts. Through the framework of the theory of heterogeneity of thinking, it was analyzed if and how the person comes to terms with contradictory areas of life.
\end{abstract}

Keywords: Contradictions, cultural-historical psychology, heterogeneity of thinking, religion.

\section{Introduction}

According to the theory of word meaning structure developed by Lev Vygotsky (1934) and later modified by Aaro Toomela (2017), it can be sensory-based thought, everyday (or situation) thought, logical thought, and structural-systemic thought. However, people tend to switch between levels of thought due to heterogeneity of the mind and thinking.

Heterogeneity of the mind means that in different areas of thought the level of thinking can be developmentally different. Nevertheless, mainstream psychology usually does not account heterogeneity of the mind and works with massive amounts of statistical data excluding individual differences (Toomela 2007, 2008).

According to Toomela (2017), religious beliefs tend to form on the stage of everyday concepts when a child is not able to distinguish pseudoconcepts from logical or structural-systemic concepts.

Recent studies show controversial results. For example, some of them show that religiosity decreases with the level of education (Kanazawa, 2010; Gervais \& Norenzayan, 2012); the others show the opposite picture (Iannaccone, 1998).

Thus, the main question is: is it correct that conflicts are resolved easier by people who have higher education or there are some other characteristics that matte more? And if these characteristics exist, what are they?

\section{Methods}

To explore people's conflicts and resolving of these conflicts, it was decided to use qualitative research. 20 semi-structured interviews were held in Russian. Religious beliefs, attitude towards religion, level of education, and personal experience were examined.

There were 20 participants: 2 people without higher education, 7 people with higher education, and 11 scientists of different spheres.

\section{Results}

In the research, there were three different kinds of approaches to faith: 8 believers, 8 non-believers (atheists), and 4 undecided (we can call them agnostics).

Some of the respondents said that scientific or professional and religious spheres do not overlap, therefore, we can assume they do not see any conflict. Some of them, on contrary, hesitate to answer and we can conclude they see the conflicts but they do not want (or do not believe they are able to) to solve it. Finally, the third category of respondents say that religious beliefs and scientific concepts cannot coexist in the human mind. 


\section{Discussion and summary}

People who tend to think on everyday level of thought, usually don't see conflicts; people who think in logical concepts, see conflicts but prefer not to think about that by different reasons; and people who have access to structural-systemic concepts, see conflicts and solve them.

There are differences between people who have relatively easy access to logical thought compared to those who mostly tend to think in everyday concepts.

The level of thought is connected to the level of education, nevertheless, there are other factors that matter. Some of the respondents were brought up in religious families and later realized themselves as atheists or agnostics. However, the opposite way from an atheist or an agnostic to a believer is a very rare case.

\section{References}

Gervais, W. M., \& Norenzayan, A. (2012). Analytic thinking promotes religious disbelief. Science, 336, 493-496.

Iannaccone, L. R. (1998). Introduction to the economics of religion. Journal of Economic Literature, 36, $1465-1496$.

Kanazawa, S. (2010). Why liberals and atheists are more intelligent. Social Psychology Quarterly, 73(1), 33-57.

Toomela, A. (2007). Culture of Science: Strange History of the Methodological Thinking in Psychology. Integr Psych Behav, 41, 6-20.

Toomela, A. (2008). Variables in Psychology: A Critique of Quantitative Psychology. Integr Psych Behav, 42, 245-265.

Toomela, A. (2017). Religion as a form of everyday conceptual thought: Evidence from orthodox icons. In: Brown, S. \& Tateo, L. (Ed.). The method of imagination. Charlotte, NC: Information Age Publishing, 191-224.

Vygotsky, L. S. (1934). Myshlenije i rech. Psikhologicheskije issledovanija. (Thinking and speech. Psychological investigations.). Moscow: Gosudarstvennoje Social'no-ekonomicheskoje Izdatel'stvo. 